\title{
Nigeria: \\ Rural Banditry and Community Resilience in the Nimbo Community
}

\author{
Jasper C. UCHE \\ Chijioke K. IWUAMADI
}

\begin{abstract}
This paper examines the upsurge in rural violence in Nigeria occasioned by the activities of armed herdsmen. Focusing on the 25 April 2016 invasion of Nimbo Community in Enugu State, the paper argues that rural governance deficit and absence of effective security tending mechanisms took a turn for the worse. The major finding is that, beyond the common conflict triggers, the factionalization of a local vigilante in Nimbo bred criminal activities that escalated the tensed milieu. Traditional qualitative method of research was applied. The paper suggests prioritization of rural security in terms of intelligence gathering, response to early conflict warning signals and combat operations, as well as a multi-stakeholder consensus in mapping out mutually-rewarding terms of engagements for the pastoralists and sedentary farmers.
\end{abstract}

Keywords: Rural Banditry, Insecurity, Agrarian Community, Herdsmen, Armed Clashes, Resilience.

Jasper C. UCHE

Department of Political Science, University of Nigeria, Nsukka

E-mail:jasper.uche@unn.edu.ng

Chijioke K. IWUAMADI

Institute for Development Studies,

University of Nigeria

E-mail: chijioke.iwuamadi@unn.edu.ng

Conflict Studies Quarterly

Issue 24, July 2018, pp. 71-82

DOI:10.24193/csq.24.5

Published First Online: 05/07/2018

\section{Introduction}

The incessant bloody clashes between the cattle herders and sedentary-farmer communities have come to pose serious human security challenges in Nigeria. Between 2010 and 2015,the country lost 6,500 persons, $\$ 14$ billion and 62,000 internally displaced in 850 perenial clashes in the NorthCentral region alone (Daily Trust,2017). Given the multi-faceted dimensions and the surrounding narratives, tracking down the perpetrators of the crime and finding solutions to the drivers became politically sensitive. In 2017, the clashes between nomadic 
herdsmen and local farmers led to at least 549 deaths and displacement of thousands in 14 states (Ameh, 2018). The killings had continued unabated with the mass burial of over 70 native farmers that lost their lives through the attacks of herdsmen in Benue State in January 2018. As such, the phenomenon of rural banditry in Nigeria has transmogrified "from crisis of nomadism to state crisis" (Ibrahim, 2016). It is also described as 'both a symptom and a cause of rural underdevelopment'(Kyari \& Chinyere, 2015).

A number of 'push and pull' factors accounted for south-ward movements of nomadic herdsmen. Firstly, drought and desertification in West African Sahelian belt occasioned the search for water and pastures beyond the original environment. Secondly, the exponential rise in cattle rustling in northern Nigeria, especially in the Kamuku forest of Kaduna, Falgore forest of Kano, Dansadau forest in Zamfara, as well as the Davin Rugu forest that stretches through the three states, contributed to the south-ward migration (International Crisis Group, 2017). Thirdly, the insurgency in the North-East, which feeds on cattle rustling, pursued the herders south-ward where they enjoyed lesser risks. Thus, transhumance has helped the pastoralists to survive the climatic crises and maintain cultural affinity (Egwu, 2015). Fourthly, population growth among the crop farmers and the increased demand for the limited land spaces for large-scale crops production pitted the two (sedentary and pastoral) farmers against the other. The clashes were usually precipitated by trespasses or movements of livestock beyond the usual transhumance corridors (where they existed), which expectedly led to destruction of crops on farmlands. The cattle herders, in turn, faced the risk of physical assaults, attacks on their lives and, in extreme cases, thievery and killings of their cattle by farmlands owners who suffered varying degrees of losses as a result of massive livestock encroachment.

In the case of Nimbo community, which had no transhumance corridor or grazing route, the herders and local farmers hitherto enjoyed peaceful co-existence. The community practiced shifting cultivation that enabled the herders to graze in the areas where farming was not done in each cropping season/year. It was a win-win strategy. However, the collapse of this constructive engagement snowballed to the armed invasion of Nimbo community on 25 April 2016. This paper is, therefore, set out to examine the conflict triggers in Nimbo community and, secondly, to analyse the coping mechanisms adopted by the community two years after the armed invasion.

\section{Conceptual and Theoretical Backgrounds}

\section{Rural banditry}

The phenomenon of rural banditry, which recently gained currency in Nigeria's public discourses, is a fallout of persistent violence in rural communities within the last ten years. The results had been traumatic. There had been massive loss of thousands of lives, forced displacement of locals and devastation of monumental proportions in 
States like Benue, Kaduna, Plateau, Zamfara, Taraba, Enugu and others across southern Nigeria. Although rural banditry is also reflected in criminal escapades like cattle rustling, kidnapping, armed robbery, drug abuse, arson, rape and other forms of violence, the brazen and gruesome massacre of agrarian communities with sophisticated weapons by suspected herdsmen and reprisal attacks from surviving victims threw it up to the front burner of national security. Pastoral Resolve (2016) notes that there is a symbiotic relationship between the two production systems-agricultural and pastoral, but conflicts had arisen because of their reliance on land and its related resources. Thus, the declining capacity of the state to moderate these conflicts and undertake effective policing of rural areas led to unending cycle of violence. The attendant resort to selfhelp worsened the security gaps in rural communities.

\section{Community resilience}

Two working definitions are presented. Firstly, the Institute for Sustainable Communities (2015) distinctively defines resilience as the ability of people, institutions and systems to manage shocks and stressors and build stronger, more prosperous communities. Secondly, Ibrahim (2017) explained the concept as "the capacity of communities to adapt when faced with hazards or shocks by taking the required actions to maintain an acceptable level of function and structure" (p. 23). Generally, community resilience entails the capacity to absorb shocks, cope with unforeseen disruptions and unpleasant emergencies. As such, it measures the ability to bounce back from setbacks by building on adaptative and proactive initiatives, to keep the victims on the path of progressive self-renewal instead of giving up or relapsing to despondency and false sense of helplessness.

\section{Theoretical perspective}

This paper is anchored on frustration-aggression model. It was propounded and captured in a monograph by five scholars in Yale Institute of Human Relations in 1939. The major assumption of the model is that "aggression is always a consequence of frustration", and "that the occurrence of aggressive behavior always presupposes the existence of frustration and, contrariwise, that the existence of frustration always leads to some form of aggression" (Dollard, Miller, Doob, Mowrer, \& Sears, 1939, p. 1). They also defined frustration as "an interference with the occurrence of an instigated goalresponse at its proper time in the behavior sequence" (Dollard et al., 1939, p. 7). The interrogations and disputations that the perspective generated led one of the proponents to intervene with some modifications of the central thesis. Thus, Miller (1941) noted that it was too general to assume that frustration must always lead to aggression or that aggression is always propelled by frustration. His intervention led to the second lap of the hypothesis which reflected a more acceptable reality thus: frustration produces instigations to a number of different types of response, one of which is an instigation to some form of aggression. 
However, fifty years later, a significant modification came from Berkowitz (1989) who argued that aggression can be driven by inherent personal benefits to the aggressor and not necessarily by past wrongdoings and that people are more akin to attack when they discover that they are wilfully sabotaged or denied what it's legitimately theirs than when the interference is an accidental occurrence. He surmised it as "frustrations are aversive events and generate aggressive inclinations only to the extent that they produce negative effect" (Berkowitz, 1989, p. 71). As already noted, the unending attacks between pastoralists and sedentary farmers across the country are largely driven by frustrations and struggles to protect the economic assets of land, cattle and farm products. Herders were pressured to provide pastures and water to their flocks in the light of climate change realities, while crop farmers were in dire need of lands for increased agricultural production. Thus, the ensuing cattle rustling, physical attacks and encroachments on farms bred frustrations between the two groups, which got effused in violent clashes and the manifest weakness of the state in curbing the menace made resort to self-help fashionable.

\section{Methodology}

Traditional qualitative research method of the social sciences was adopted. This method includes gathering data from primary sources through interviews of key informants drawn from Nimbotown union leadership structure and interactions with relevant stakeholders identified within Uzo-Uwani Local Government Area (LGA). The interviews were guided by a set of predetermined questions. In addition, secondary data were sourced and largely used to complement shortfalls of the interviews and interactions. Here, a desk review of relevant literature like scholarly articles, government reports, submissions to panel of inquiry, media accounts, and publications of non-governmental organizations (NGOs) were analysed. These materials were sourced from various knowledge repository centers and platforms.

\section{Agrarian Practices in Nimbo Community}

Nimbo is a border town in Uzo-Uwani LGA of Enugu State, South East,Nigeria. Other towns in the border within the LGA include: Adani, Ogurugu, Igah, Opanda, Abbi, Ezikoloand Nrobo. Nimbois blessed with rich, fertile and large expanse of land that stretches towards Eshi River, the boundary between Enugu State and Kogi State. The huge agricultural potentials of the area attracted the first President of Nigeria - Dr Nnamdi Azikiwe to set up a family farm there. The then Premier of Eastern Region, Late Dr. M.I. Okpara also established a farm settlement in the community as part of the defunct Eastern Regional Government agrarian policy. The foregoings led to continued influx of persons to Nimbo community as far back as 1922 .

Geographically, the farms were located at about $7 \mathrm{~km}$ from their residences. The farmers used to trek to and fro the bush paths on daily basis in order to access, work and 
harvest their farm products. For convenience and to save man-hours, the progenitors of the community used to build makeshift huts in the farm areas where they could sleep for consecutive three days and return on the (Eke Market) day at home to sell their farm products. The farm products included: cassava, yam, groundnut, garden eggs, cucumber, plantain etc. Thus, the community enjoyed peaceful co-existence with their neighbours and settlers. A key stakeholder in Nimbo community noted that even when herdsmen came and settled in the 1990s, they lived harmoniously with the locals, and compensated owners of farms whenever their cattle caused unintended damages. However, as destructions on farmlands increased with entrance of more herders, the indigenous farmers wanted the cattle to be labelled for easy identification. This was rebuffed by the 'newest' herdsmen and they relocated from the community. They resisted all entreaties to abide by the subsisting practice. In 2001, 'they returned with aggression and it is on record that that they killed our people yearly' (personal communication, May 4, 2017). In retaliation for the dead, Nimbo people killed their cows.

According to a Memorandum from Nimbo community to the Judicial Panel of Inquiry set up by Enugu State after the April 26 attack, Mr. Ogobe Dieke was shot in 2005; in October 2010, a school teacher - Mr. Charles Igwebueze was killed by herdsmen; on July 19, 2012, Messers Michael Oke and Thaddeus Utazi were brutally murdered in their farms. In June 2013, the two members of a local vigilante - Messrs Ozoemena Eze and Onyemachi Ajogwu were ambushed and killed on their way to respond to distress calls from the farms. There were also cases of rape, armed robbery, armed assaults, kidnap-for-ransom and general air of insecurity facilitated by brandishing of dangerous weapons by the herdsmen. When the herdsmen who abandoned the Nimbo axis came back, they settled at Enugu - Kogi border. By that time, cases of armed attacks started happening. Attempts by the traditional ruler of Nimbo to prevail on the herdsmen from attacking his people could not yield result as the leaders of the herdsmen did not show up at a meetings cheduled at the palace of the paramount ruler of Igalaland (Attah Igala) in neighbouring Kogi State (where the herdsmen largely operated from). Apparently, they were yet to come to terms with the killings of their cattle allegedly perpetrated by Nimbo gangsters. On one hand, the local farmers felt frustrated by the massive destructions in their farms by cattle rearers, hence they opted for killing and stealing of cattle. On another hand, the herdsmen recounted their losses and the risk their businesses face in Nimbo, and resorted to bloody confrontation with the locals. Thus, frustration bred the aggression in Nimbo community.

\section{Armed Invasion of Nimbo Community}

On April 25, 2016, Nimbo community witnessed a bloody invasion and massacre of locals by suspected armed herdsmen. The seven villages in Nimbo (Nimbo Ngwoko, Ugwuijoro, Ekwuru, Ebor, Enugu Nimbo, Umuome and Ugwuachara) were the most affected. They first attacked Ngwoko village and young boys flee from the area. Before 
then, rumour had filtered that the herdsmen would attack Uzo-Uwani LGA. This created anxiety in Nimbo. In fact, 'it was gathered that herdsmen at Adani had at the weekend imported 500 others from Nassarawa State to help them invade Nimbo community' (This Day, 2016). Also, the complaints of rape and kidnapping along Adani-Umulokpa Road elicited growing concerns. But the security report of impending attack by herdsmen was swiftly reported to the Governor of Enugu State and the Commissioner of Police. A meeting with Fulani leaders in the state was convened two days before the armed attack. The Fulani leaders confirmed that there were attempts to bring in mercenaries from Nassarawa to retaliate the killings of their people within the axis of Nimbo and Abbi communities. It was resolved at the meeting that the Fulani leaders would dissuade their people from embarking on violent attacks, but that could not happen. Two days later, numerous armed men invaded Nimbo in the early hours of Monday, 25 April, and left the community with unimaginable carnage and destruction of property. The ugly event occured 30 minutes after the security operatives policing the community reportedly deserted their duty posts (Nimbo town union leader, personal communication, May 4, 2017). According to the Memorandum submitted by Nimbo community to the Judicial Panel of Inquiry set up by Enugu State Government, at least 13 persons were killed, while about N100 million (US $\$ 279,000$ ) was lost in ten burnt buildings,vehicles, motorcycles, slaughtered domestic animals, as well as many persons that got severely wounded and deep matchets while escaping the marauding herdsmen.

Beyond the deterioration of the security climate in Nimbo, the economic activities nosedived considerably. People especially women and children, could no longer go to farms freely except accompanied by able-bodied men or local vigilante. The rural markets Eke Nimbo, AforUkpabi and Opanda known for cheap and affordable farm products and which used to be bee-hive of commercial activities degenerated into near-extinction. The rumours of more reprisal attacks turned the community into a ghost town. Two women (Mrs. Agnes Ajogu and Mrs. Eberechukwu Ako) whom their husbands were matcheted to death in their presence suffered from trauma-induced madness (The Sun, 2016). It took the re-assurances of Enugu State Government and heavy police presence along Enugu-Kogi border to bolster the people's confidence and the return of displaced persons back to Nimbo.

\section{Undercurrents of Nimbo Security Breach}

Three outstanding issues contributed to the security breach in Nimbo community. Firstly, is the complacency/politicization of crisis by government. Secondly, is connivance of security operatives and thirdly is the Nimbo community's internal contradictions.

a. Complacency/ politicization by Government: Despite the serial carnage of the herdsmen and its labelling as the fourth deadliest terror group in the world in 2014, Nigeria's government failed to decisively deal with the rampaging security 
threat. It was widely believed that President Buhari's loud silence over the matter was on account his business interest. He was a one-time patron of Miyetti Allah Cattle Breeders Association (MACBA). Oyeyipo, James and Sanda (2016) noted that the authorities perceived the violence as 'a mere internal security challenge with ethnic colouration'. Herdsmen were scarcely arrested and prosecuted even after massive killings and razing down of communities. In fact, it took public pressure to elicit initial condemnations of the internecine strife from President Buhari. Hence, there was little or no clear-cut measure to tackle the menace. The dismissive dispositions of a section of the ruling class (who are largely owners of the livestock) also festers the debacle. Besides, the different ethno-religious backgrounds of the combatants - (the herders are mostly Muslim Fulani, while the crop farmers are mostly Christians from other ethnic extraction) led to the politicization of the armed conflict. Incrementally, the unsettling crisis sets centrifugal sentiments and security fears on alarming crescendo so, when the savagery played out in Enugu State, the Governor of the State appeared helpless. The weeping of the Governor Ifeanyi Ugwuanyi at the scene of horrific incident at Nimbo left much to be desired. Again, the inability of Enugu State Government to issue a white paper on the findings of Judicial Panel of Inquiry that investigated the crisis after two years depicts a lack of political will to address the national catastrophe.

b. Connivance of security operatives: Nimbo case is a clear example of avoidable violence that occurred due to culpable negligence and manipulation of the security structure. At the receipt of intelligence report on Nimbo case, the Governor Ugwuanyi summoned an emergency security council meeting which was attended by the heads of security formations. There were assurances of deployment of men of Anti-Terrorism Unit (ATU), Special Anti-Robbery Squad (SARS) and the Police Mobile Force (PMF) to Nimbo by the Police Commissioner, as well as the claim of deployment of military to Nimbo by the Garrison Commander to forestall the attack. The Governor recounted that "the State Government provided logistics for these deployments' and 'after receiving these assurances of deployments to Nimbo, I felt quite confident that we had done everything possible to forestall an attack on Nimbo" (Vanguard, 2016). Evidence from the community indicated that prior to the day of attack, there was a combined team of soldiers, policemen and men of Nigeria Security and Civil Defence Corps (NSCDC) deployed to the community (The Guardian, 2016). But what created suspicion was the abandonment of duty posts in the community by the security agents and, in less than one hour, the armed invaders swooped in on the community. Up till today, nobody in the top echelon of security agencies had been called to account for the alleged official complicity. The Commissioner of Police was immediately transferred to another state yet lives had been lost. Who ordered the security operatives to step off from Nimbo? What could be the motive? If it was a mere coincidence, was there a counter intelligence report or directives that warranted 
the sudden exit of all the security personnel? However, Governor Ugwuanyi pushed the blame to the doorsteps of security operatives thus: "What happened between 6.30 am and 7.30 am on Monday 25 April, 2016 despite assurances from the Security agencies? Only the Security Agencies can answer this question" (Vanguard, 2016).

c. Nimbo community's internal contradictions: Nimbo crisis has several narratives with political undertones. What is however under-reported was the factionalization of the community based on 'Igweship' and 'Ezeship' traditional authorities tussle between Ukpabi Nimbo and Oda Nimbo, which led to a formation of a parallel vigilante group officially known as -Neighbourhood Watch (personal communication, KII, 8 August 2017). Neighbourhood Watch is the government-recognised local vigilante group that operates in Enugu State. The words of the key informant which is often overlooked captured it vividly: "There is a group of boys that formed neighbourhood watch within Nimbo community, and these boys started abusing their powers by stealing cows, then they ate or sold them in the name of revenge of destruction of their farm crops by herdsmen activities" (personal communication, August 8, 2017).

Expectedly, a supremacy contest between the two groups added a new twist to the security vacuumin the area. It was revealed that the parallel vigilante's involvement in cattle rustling triggered the herdsmen retaliation. The parallel group also kidnapped those who stood against them. Mr. Ejiofor Enechi, a security advisor to the Chairman of Uzo-Uwani LGA was a victim. He was accused of revealing the parallel vigilante's criminal plots to herdsmen,and exposing the group as those who usually attacked and stole money and cattle from herdsmen in the bush in Oda Nimbo (Vanguard, 2017). Thus, the community leaders enmeshed in the local political crisis lacked the overarching influence to curb the raging youth gangsterism.G overnment on its on part, either out of negligence, lack-lustre threat analysis or poor response to early conflict warning signals, failed to nip the ugly development in the bud, which could have averted the preponderance of banditry in Nimbo community. Thus, the illegal operations of the parallel vigilante body and their criminal escapades against the herdsmen in the community triggered the armed retaliation from the herdsmen.

\section{Coping Strategies by Nimbo Community}

Since the attack on Nimbo, the psychological trauma meted out to the community lingered, regardless of the survivalist resolve of the people to move on. Beyond the public empathy and torrents of condemnations that trailed the armed invasion, the ability of the community to bounce back to reckoning is gravely undermined by governance failure and insensitivity of the ruling class. Although there were relief materials from humanitarian bodies and stop-gap interventions by Enugu State Government yet the nearabsence of political will to address the conflict drivers raises fundamental questions. International Crisis Group (2017) notes that the federal and state governments 'have 
done little or nothing to address rural insecurity...federal security and law enforcement agencies have established neither early warning nor rapid response mechanisms; they have not arrested and prosecuted the perpetrators of violence or offered redress to the victims' (p. 3).

Notwithstanding the deployment of stand-by Police Moblie Force along Nsukka-Adani Road, (which boosted the people's confidence), the abandonment of building of a permanent Intervention Centre at the border, promised by the former Nigerian Inspector General of Police, Solomon Arase, indicates the usual official lip-service to rural insecurity. However, Nimbo community's quest to take their destiny in their hands led to disbandment of the hitherto vigilante group that was accused of aiding and abetting kidnappings and assassinations before the April 25 attack. A new Neighbourhood Watch (NW) was set up, funded and equiped by the members of the community. Women and children no longer go to farm alone. They go in groups and NW members usually climb on top of trees to monitor the activities of herdsmern while the farmers are busy in their farms. At a super-structural level, Uzo-Uwani LGA also recruited about 30 men in the local government NW that complement the police in local intelligence and tracking down of criminal elements. Nimbo has witnessed less tension as a result of the seproactive measures.

However, the demand of Nimbo community for herdsmen to either leave the community entirely or take the option of grazing on fallow grounds were scarcely met. Ordinarily, the mayhem on the community should make the herdsmen to relocate elsewhere but today, 'they are still everywhere in Uzo-Uwani with their guns and matchets and no government or security agency had accosted them despite that so much is spent on monthly security votes and budgets' (stakeholder, personal communication, August 8 , 2017). This betrayed the impunity of the ruling class on foisting the idea of open grazing despite popular disapproval, especially among the southern part of the country. There were still reported cases of kidnapping, killings and pockets of banditry within the LGA even though the Nigerian Police had made significant breakthroughs in bursting the kidnapping ring. Our key informant suggests that the hands of local elites may be implicated in the sponsorship of kidnappings in the area; as the rag-tag attire of suspected kidnappers indicates that 'the money they are making is not for them but for some "big" men who they work for' (stakeholder, personal communication, August 8, 2017).

The arraignment of five suspects (Fulani and Kanuri herdsmen) at Nsukka High Court for their alleged roles in the 25 April 2016 invasion of Nimbo, and the excitement it elicited showed the community's craving for justice for the victims. Thus, the fastest healing process for Nimbo locals is for governments at all levels to be seen impartial, and not condone perpetrators of dastardly acts. 


\section{Conclusion}

From the foregoing, it was discovered that that armed invasion of Nimbo community is similar to the clashes witnessed between herdsmen and sedentary farmers across Nigeria. The combatants (herders and farmers) felt frustrated in the conduct of their businesses and hence, they resorted to self-help in the face of security vacuum and governance failure. The crises were largely driven by the tendency to protect and preserve economic assets (lands, farms and cattle) on one hand, and the absence of political will to tackle the menace by governments, on the other hand. Thus, the break down of constructive engagement with herders in Nimbo and criminalization of chieftaincy tussles sparked off pent-up emotions in an already tensed environment. The poor response to early conflict warning signal and lack-lustre approach of security agencies resulted in the avoidable destruction of lives and property in Nimbo. The inability to manage the frustrations faced by the nomadic herdsmen and local farmers led to the aggression of 26 April 2016. Generally, while Nimbo community has struggled to get over the tragedy, their resilence has been dogged by infrastructure gap, rural negligence and horizontal inequalities accentuated by governance deficit.

\section{Policy Recommendations}

a. To ensure water-tight security in rural areas, governments should devote commensurate personnel and resources towards local intelligence gathering, early conflict warning signalling, and combat operations complemented by well-trained and wellregulated community vigilantes.

b. Re-establish grazing reserves and stock routes in consenting areas with a multistakeholder buy-in. There should be absence of manipulation of legal and political institutions to foist on the people the preferences of the ruling class.

c. Since cattle rearing is a private business, ranching remains the safest and less controversial option to discourage frequent contacts with sedentary farmers. More important, nomadic lifestyle is obsolete and raises human rights concerns in the $21^{\text {st }}$ century.

d. To curb the menace of cattle rustling, the federal government should encourage the evolving initiative of the Nigerian Police to develop tracking and animal identification technologies.

e. The ECOWAS Protocol on free movements of persons and goods needs to be reevaluated in the light of health and security implications of unregulated influx of nomads from Sahelian belt. Adequate resources (manpower and logistics) should be deployed to effectively police the national borders, which are largely porous; and to also checkmate illegal inflow of small arms and light weapons into Nigeria's territory.

f. Governments should summon the political will (without fear or favour) to prosecute the criminal elements masquerading as herdsmen or crop farmers for deterrence value and justice to victms of banditry. Security operatives should undertake 
community-friendly mop-up operations and sanitise the civil space of ubiquitous arms cache by unauthorized persons.

g. The expectations of Nimbo people from the anticipated government white paper resulting from the Judicial Panel of Inquiry should not be dashed. Government, as a matter of urgency, should make public the Panel's findings (which is long overdue), to give justice to the victims, and allaythe suspicion of bias and favouritism.

\section{References:}

1. Ameh, C. G. (2018, January 30). Amnesty International Reveals How Many Nigerians Fulani Herdsmen Killed in 2018. Daily Post. Retrieved from http://dailypost.

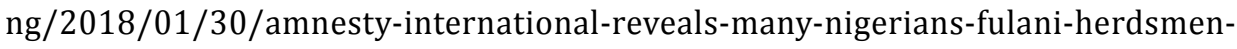
killed-2018/.

2. Berkowitz, L. (1989). Frustration-Aggression Hypothesis: Examination and Reformulation. Psychological Bullettin, 106(1), 59-73.

3. Daily Trust. (2017, September 25). 6,500 Killed, \$14bn Lost to Herders/Farmers Clashes - Report. Daily Trust. Retrieved from https://www/dailytrust.com.ng/6-500-killed14bn-lost-to-herders-farmers-clashes-report.html.

4. Dollard J, Miller, N. E, Doob, L. W., Mowrer, O. H., \& Sears, R. R. (1939). Frustration and Aggression. New Haven, CT: Yale University Press.

5. Egwu, S. (2015). The Political Economy of Rural Banditry in Contemporary Nigeria. In M. J. Kuna and J. Ibrahim (Eds.), Rural Banditry and Conflicts in Northern Nigeria (pp. 14-67). Abuja: Centre of Democracy and Development (CDD).

6. Ibrahim, J. (2016, April 4). Rural Banditry: From the Crisis of Nomadism to State Crisis. Daily Trust. Retrieved from https://www.dailytrust.com.ng/news/opinion/rural-banditry-from-the-crisis-of-nomadism-to-state-crisis.

7. Ibrahim, J. (2017, May 12). The Resilience of Nigerians. Daily Trust. Retrieved from https;//www.dailytrust.com.ng/news/Friday-column/the-resilience-of-nigerians/197464.html.

8. International Crisis Group. (2017, September 19). Herders Against Farmers: Nigeria's Expanding Deadly Conflict, Report No 252/ Africa. International Crisis Group. Retrieved from https://wwwcrisisgroup.org/Africa/Nigeria/252-herders-aganst-farmers-nigerias-expanding.

9. Institute for Sustainable Communities. (2015, November 5). What is Community Resilience and Why Does it Matter?. ISC. Retrieved from www.iscvt.org/what-is-community-resilience-and-why-does-it-matter/.

10. Kyari, M., \& Chinyere, A. (2015). Social Impact of Rural Banditry. In In M. J. Kuna and J. Ibrahim (Eds.), Rural Banditry and Conflicts in Northern Nigeria (pp.167 -188). Abuja: Centre of Democracy and Development (CDD).

11. Miller, N. E. (1941). The Frustration-Aggression Hypothesis. Psychological Review, 48, 337-342. 
12. Oyeyipo, S., James, S., \& Sanda, J. (2016, May 2). The New Terror Threat. This Day. Retrieved from https://www.thisdaylive.com/index.php/2016/05/02/the-new-terrorthreat/.

13. Pastoral Resolve.(2016, June 5). Addressing Rural Banditry in Northern Nigeria: A Policy Brief.Pastoral Resolve. Retrieved from https://pastoralresolve.blogspot.com. ng/2016/06/addressing-rural-banditry-in-northern.html.

14. The Guardian. (2106, May 1). When Herdsmen Spewed Death on Community. The Guardian. Retrieved from https://guardian.ng/sunday-magazine/when-herdsmenspewed-death-on-community/.

15. The Sun. (2016, June 15). Nimbo Attack: Trauma Causes 2 Women to Go Mad. The Sun. Retrieved from sunnewsonline,com/nimbo-attack-trauma-causes-2-women-to-go$\operatorname{mad} /$.

16. This Day. (2016, May 1). The Bloodletting by Herdsmen in Enugu. This Day. Retrieved from https://www.thisdaylive.com/index.php/2016/05/01/the-bloodletting-byherdsmen-in-Enugu/.

17. Vanguard. (2016, April 30). I Alerted Security Operatives Before Fulani Herdsmen Attack, says Ugwuanyi. Vanguard. Retrieved from https://www.vanguardngr. com/2016/04/i-alerted-security-operatives-before-fulani-herdsmen-attack/.

18. Vanguard. (2017, February 25). Why We Kidnapped Council Security Boss in Enugu - Suspects. Vanguard. Retrieved from https://www.vanguardngr.com/2017/02/kidnapped-council-security-boss-enugu-suspects/. 